\title{
Państwowe Seminarium Nauczycielskie Żeńskie w Piotrkowie w pierwszych latach działalności (1916-1919). W stulecie powstania
}

\author{
State Female College in Piotrków in the First Years \\ of Its Activity (1916-1919). \\ On the Centenary of Its Establishment
}

\begin{abstract}
ABSTRAKT
Państwowe Seminarium Nauczycielskie Żeńskie w Piotrkowie powstało w 1916 roku w okresie okupacji austriackiej. W poczqtkowych latach nauczyciele
\end{abstract} istnienia swoja działalność prowadziło $\mathrm{w}$ oparciu o przepisy sformułowane dla czteroklasowych seminariów galicyjskich. Jego celem było przygotowanie kadr pedagogicznych dla szkół elementarnych, zwłaszcza wiejskich. Przy seminarium utworzono czteroklasowa szkołę ćwiczeń, niezbędnq dla osiqgnnięcia praktycznych umiejętności zawodowych przyszłych nauczycielek. Zakład wzorowo rozwijał działalność dydaktycznq i wychowawczq. Troszczył się również o stronę materialnq uczennic. Prowadził interesującq pracę pozalekcyinq. Bardzo korzystnie zaznaczył swojq obecność w życiu miasta. Poczq̨kowo większość nauczycieli seminarium, podobnie jak jego dyrektor dr Jan Magiera, wywodziło się z Galicji. Aktywnie uczestniczyli oni

KEY WORDS

female college, education, subjects, female students, teachers

SPI Vol. 19, 2016/3

ISSN 2450-5358

e-ISSN 2450-5366

DOI: 10.12775/SPI.2016.3.010

Artykuły i rozprawy 
w dokształcaniu i doskonaleniu kadr nauczycielskich regionu piotrkowskiego. Pierwsza matura w seminarium odbyła się w czerwcu 1919 roku. Po dwudziestu latach istnienia, seminarium zakończyło działalność w 1936 roku. Jego mury opuściło 397 wykwalifikowanych nauczycielek szkół powszechnych. Piotrków Trybunalski jako ośrodek kształcenia nauczycieli trwa nieprzerwanie od 100 lat do dnia dzisiejszego.

\section{ABSTRACT}

State Female College in Piotrków was established in 1916 in the period of Austrian occupation. In the first years of its activity it operated on the basis of rules formulated for four - grade Galician colleges. Its purpose was to prepare pedagogical staff for primary schools, especially the country ones. A four-grade training school was also established as part of the college so that future teachers could acquire practical skills for their jobs. The college developed perfectly its educational activity. It also took care of the financial situation of its students. Moreover, the school engaged in interesting extracurricular activities. The whole town benefited greatly from the fact that the college existed there. Initially, the majority of the college teachers, like the head teacher Phd Jan Magiera, came from Galicia. They actively participated in educating and training the teaching staff of the Piotrków region. The first school leaving exam was taken in the college in June 1919. After twenty years, the college finished its activity in 1936. Altogether 397 qualified female teachers left the college.

\section{Wprowadzenie}

Kwestia zapewnienie wykwalifikowanych kadr pedagogicznych dla szkolnictwa ma Polsce wielowiekową tradycję. Świadczy o tym utworzenie pierwszego seminarium nauczycielskiego przez jezuitów w Pułtusku już w 1571 roku oraz następnych w Poznaniu i Jarosławiu (1575 r.), a także w Dorpacie (pod koniec XVI w.) ${ }^{1}$.

1 L. Piechnik SJ, Poczatki seminariów nauczycielskich w Polsce w wieku XVI, w: $Z$ dziejów szkolnictwa jezuickiego w Polsce. Wybór artykutów, oprac. J. Paszenda SJ, Kraków 1994, s. 66-73. Interesująca też jest jezuicka koncepcja ideału nauczyciela, por. S. Bednarski SJ, Upadek i odrodzenie szkót jezuickich w Polsce. 
Dopiero ponad 200 lat później powstały powszechnie znane seminaria nauczycielskie z inicjatywy Komisji Edukacji Narodowej. Po utracie niepodległości brak nauczycieli dla szkolnictwa odczuwalny był na ziemiach polskich we wszystkich zaborach. Najbardziej widoczny był jednak ogromny niedostatek nauczycieli dla szkół elementarnych, a następnie początkowych w Królestwie Polskim. Narastał on w drugiej połowie XIX i na początku XX wieku, wraz z rozwojem szkolnictwa rządowego oraz pojawianiem się szkół prywatnych. Kwestia kształcenia nauczycieli była też istotna przede wszystkim z tego powodu, że decyzją władz carskich zalecano przygotowanie kadr nauczycielskich, których podstawowym zadaniem miało być skuteczne realizowanie zarządzeń w sprawie stosowania $\mathrm{w}$ procesie nauczania w szkołach języka rosyjskiego. Wprowadzeniu w życie tej idei służyć miało między innymi ukazanie się Ustawy kursów pedagogicznych dla ludności polskiej w Królestwie Polskim $\mathrm{z}$ dnia 5 (17) stycznia $1866 \mathrm{roku}^{2}$.W rezultacie jej natychmiastowej realizacji już rok później istniało na terenie Królestwa 7 kursów pedagogicznych ${ }^{3}$. W latach $1872-1873$ kursy te przemianowano na trzyletnie seminaria nauczycielskie. W roku szkolnym 1874/1875 było ich w Królestwie Polskim 94. Zapis ustawy z 1866 roku został zrealizowany w późniejszych latach również w Piotrkowie, gdy miasto umocniło swoją pozycję i znaczenie jako centrum administracyjne oraz stolica uprzemysłowionej guberni. Przy miejskiej szkole aleksandryjskiej uruchomiono klasy pedagogiczne, dające elementarne kwalifikacje zawodowe przyszłym nauczycielkom szkół początkowych ${ }^{5}$.

Studium z dziejów kultury i szkolnictwa polskiego, Kraków 1933. Reprint wykonało Wydawnictwo WAM w 2003 r., s. 376 i passim. Trzeba tu dodać, że jezuici kształcili kadry nauczycielskie dla swojego systemu szkolnego także w innych formach edukacyjnych.

2 Dziennik Praw, Drukarnia Rządowa przy Komisji Rządowej Oświecenia Publicznego, Warszawa 1866, t. 64, nr 209, s. 233-303.

3 R. Kucha, Oświata elementarna w Królestwie Polskim w latach 1864-1914, Lublin 1982, s. 77.

4 Tamże, 9.

5 J. Kulpa, Ksztatcenie nauczycieli szkót powszechnych w Polsce w latach 1918-1939, Zakład Narodowy im. Ossolińskich, Wrocław 1963, s. 14. 


\section{Powstanie seminarium}

Piotrkowska szkoła nauczycielska, którą umieszczono na parterze budynku byłego gimnazjum żeńskiego z rosyjskim językiem wykładowym, przy ul. św. Anny (obecnie ul. Stronczyńskiego 1), podjęła działalność na dosyć specyficznych zasadach. $Z$ jednej strony jej praca opierała się na przepisach sformułowanych dla żeńskich seminariów nauczycielskich obowiązujących w Galicji oraz na opracowanym dla tych zakładów statucie ${ }^{6}$, $z$ drugiej zaś uwzględniała realia związane $\mathrm{z}$ tradycją i konkretnymi uwarunkowaniami istniejącymi na obszarze jej działalności. Już przy przyjmowaniu na pierwszy kurs seminarium musiano wziąć pod uwage poziom i zakres wykształcenia kandydatek, wynikający z istniejącego w Królestwie Polskim systemu szkolnego i braku klas przygotowawczych, istniejących przy galicyjskich zakładach kształcenia nauczycieli. Warunkiem zapisu dziewcząt do seminarium było: 1) ukończenie co najmniej 15 roku życia, 2) odpowiednia sprawność fizyczna, 3) nieskazitelna moralność, 4) określony zasób wiedzy. Wymogi te pokrywały się z przepisami przewidzianymi dla seminariów galicyjskich, w niektórych jednak miejscach były odmienne i odpowiednio dostosowane do aktualnych potrzeb lokalnych. Przy wpisie oczekiwano przedłożenia metryki urodzenia, świadectwa o zdrowiu (w 1918 roku zalecano uwzględnić w nim ewentualne choroby oczu, płuc, zaświadczenie o szczepieniu przeciw ospie) i sprawności fizycznej, stwierdzającego brak upośledzenia umysłowego i rażących wad wymowy, świadectwa moralności (nie określono, kto je miał wystawiać), jeśli bezpośrednio przed ubieganiem się o przyjęcie kandydatka do seminarium nie uczęszczała do szkoły. Należało również przedstawić ostatnie świadectwo szkolne i zdać egzamin wstępny. W pierwszych dwóch latach istnienia szkoły zakres wymagań egzaminacyjnych w każdym roku określało grono pedagogiczne. Zmuszało to nauczycieli do znacznego wysiłku i przyjęcia dużej odpowiedzialności. Dziewczęta,

6 Przepisy o ksztatceniu nauczycieli oraz o uzdolnieniu do nauczania w szkotach ludowych w Galicji, w: Dodatek do Dz. U. c. k. Rady Szkolnej Krajowej, Nakł. c.k. Rady Szkolnej Krajowej, Lwów 1909, s. 1-89; por. też: Cz. Majorek, Galicyjskie koncepcje organizacji szkolnictwa pedagogicznego, „Rozprawy z dziejów oświaty" 1968, t. 11, s.127-148, 158-165; A. Meissner, Spór o dusze polskiego nauczyciela. Spoteczeństwo galicyjskie wobec problemów nauczycieli, Rzeszów 1999, s. 197-199. 
które miały ukończone co najmniej cztery klasy szkoły średniej, zwolnione były z egzaminu wstępnego.

Równolegle z rekrutacją uczniów do seminarium przyjmowano dzieci od szóstego roku życia do nowo utworzonej szkoły wzorowej (szkoły ćwiczeń). Okolicznością sprzyjającą utworzeniu seminarium był fakt istnienia w mieście dobrze działających ogródków dziecięcych, w tym jordanowskiego. W pierwszym roku pracy seminarium zdołano uruchomić naukę na kursie I (20 uczennic) i II (9 uczennic) oraz w koedukacyjnej szkole ćwiczeń (klasa I - 21 uczniów, klasa II 31 uczniów) ${ }^{7}$. Sporo przyszłych nauczycielek rekrutowało się spośród niższych sfer społecznych. Stąd też seminarium w oczach tych piotrkowian, którzy posyłali swoje córki do dwóch prywatnych pensji, z których szkoła Henryki Domańskiej (wychowanki Krzywickich) miała charakter ekskluzywny, zyskało miano „biedniackiego”, czy też „szkoły dla służących”. Część mieszkańców miasta niezbyt przychylnie odnosiła się także do faktu, że seminarium założył okupant, a dyrektor szkoły dr Jan Franciszek Magiera ${ }^{8}$ chodził początkowo w mundurze austriackim. Taka atmosfera wokół nowej placówki trwała 3 lata i nie sprzyjała jej rozwojowi ${ }^{9}$. Przyjazne wsparcie, w tym

$7 \quad$ I Sprawozdanie dyrekcji Publicznego Seminarium Żeńskiego w Piotrkowie za rok szkolny 1916/17, Piotrków 1917, s. 19.

8 Szerzej na temat J. Magiery: W. Grzybek, Magiera Jan Franciszek, w: Polski stownik biograficzny, t. XIX, Kraków 1974, s. 133, 134; M. Borowiecka, Jan Magiera 1876-1958, „Pamiętnik Słowiański” 1960, t. X, s. 186-190. Dr Jan Franciszek Magiera (15 grudnia 1876-19 marca 1958), filolog polski i germański, slawista, absolwent Uniwersytetu Jagiellońskiego. Pracował w Gimnazjum Św. Jacka w Krakowie, Gimnazjum w Nowym Sączu i Gimnazjum V w Krakowie. W latach 1916-1928 był dyrektorem piotrkowskiego seminarium. Aktywnie uczestniczył w życiu miejscowego środowiska oświatowego. Od 1928 roku do czasu przejścia na emeryturę w 1932 r. kierował VII Gimnazjum w Krakowie. W latach 1945-1952 był lektorem języków czeskiego i słowackiego na Uniwersytecie Jagiellońskim. Autor kilku książek i wielu artykułów naukowych oraz popularnonaukowych z zakresu słowianoznawstwa. Publikował m. in. na łamach „Świata Słowiańskiego”, „Przeglądu Powszechnego”, „Nowej Reformy”, „Ilustrowanego Kuriera Codziennego”, „Kuriera Łódzkiego” i piotrkowskiego „Dziennika Narodowego”. Swoje przemyślenia na tematy pedagogiczne zamieszczał w „Muzeum”, „Szkole”, „Oświacie” $\mathrm{i}$ innych pismach. Jego dorobek obejmuje ponad tysiąc prac. Wiele podróżował po krajach słowiańskich. Był człowiekiem bardzo skromnym.

9 A. Matusiakowa, Przyczynki do badań nad rozwojem szkolnictwa nauczycielskiego w Piotrkowie Trybunalskim. Dokumenty walki mtodych Ziemi Piotrkowskiej z okupantem hitlerowskim w latach 1939-1945, Łódź 1993, s. 13, 29. 
materialne, płynęło natomiast ze strony władz miasta, przedstawicieli wojska austriackiego i lokalnej prasy ${ }^{10}$. Wielkim przyjacielem szkoły był aptekarz piotrkowski Michał Rawita Witanowski ${ }^{11}$.

\section{Praca u podstaw. Pierwszy rok pracy edukacyinej}

Działalność seminarium wraz ze szkołą wzorową zainaugurowano 8 listopada 1916 roku mszą św. w kościele farnym, z udziałem przedstawicieli szkół piotrkowskich. W przemówieniu wygłoszonym podczas uroczystego otwarcia J. Magiera stwierdzit: „Wielkie i wdzięczne zadanie ze szlachetnym celem czeka młode Polki, co już czasu wojennego w seminariach nauczycielskich przygotowywać się i sposobić do zaszczytnej roli poczęły. Przed wojną działalność oświatowa niewiast polskich tu w środku polszczyzny i polskości odbywała się niejako w katakombach, pod powierzchnią życia codziennego jawnego, strzeżonego przenikliwym okiem ochrany wszelakiej. Teraz mogą wyjść na światło publiczne i kształcić młódź narodową"12. Dyrektor był przekonany, że seminarzystki rozpoczynające naukę będą gotowe do pracy w najodleglejszych zakątkach wolnej Polski. Podkreślając, iż „na wiejskim zagonie duchowym wdzięczna orka i owocna”, uznał, że podstawowym zadaniem przyszłych nauczycielek będzie nauczenie dzieci czytania i pisania oraz zaszczepienie im „żądzy wiedzy”. Wskazał na potrzebę nieustannego zachęcania do nauki, aby w ten sposób ustrzec dziecko wiejskie przed wtórnym analfabetyzmem. Zadaniem absolwentek seminarium powinno być nie tylko kształcenie, ale i wychowywanie uczniów, przyswajanie im „form i zwyczajów towarzyskich” oraz codziennej higieny. Przyszłe nauczycielki powinny uczyć podopiecznych demokratycznych, nowoczesnych zasad życia, oraz przekazywać im praktyczną wiedzę z zakresu gospodarstwa domowego, ziołolecznictwa, robienia przetworów domowych z warzyw i owoców. Magiera postrzegał w nowoczesny sposób

10 I Sprawozdanie dyrekcji Publicznego Seminarium Żeńskiego w Piotrkowie za rok szkolny 1916/17, dz. cyt., s. 15.

11 A. Matusiakowa, Przyczynki do badań nad rozwojem szkolnictwa nauczycielskiego w Piotrkowie Trybunalskim. Dokumenty walki mtodych Ziemi Piotrkowskiej z okupantem hitlerowskim w latach 1939-1945, dz. cyt., s. 30.

12 J. Magiera, Nauczycielka na wsi, w: I Sprawozdanie dyrekcji Publicznego Seminarium Żeńskiego w Piotrkowie za rok szkolny 1916/17, dz. cyt., s. 3. 
rolę nauczycielki w społeczności lokalnej jako działaczki społeczno-kulturalnej, popularyzatorki czytelnictwa, organizatorki pogadanek i odczytów w miejscu zamieszkania, animatorki zespołów chóralnych i uroczystych obchodów ważnych rocznic oraz świąt narodowych.

Nauczyciela przyrównywał do księdza. „Jak ideałem ojca duchownego jest mi ksiądz co w swej parafii od domu do domu się przejdzie, przygodnie i wiary pouczy i w doli ziemskiej doradzi, tak i nauczyciel idealny mój z każdym się domem zapozna, wszędzie da jakąś radę skuteczną i zawsze czegoś ze swej wiedzy udzieli. Niech jakby jakiś gromadzki siewca rozsiewa naukę i wiedzę po wiosce i chatach. Taką przechadzkę doradzam nauczycielce"13.

Dyrektor dostrzegał wielką rolę nauczycielek w gospodarczo-społecznym rozwoju wsi. Uważał, że powinny świecić przykładem, wiedzą i praktyczną działalnością w zakresie uprawy warzyw, hodowli drobiu, stanowić swym postępowaniem wzór godny naśladowania dla gospodyń wiejskich. Proponował, aby przyszłe nauczycielki wspomagały ruch spółdzielczy i handel wiejski. Apelował, aby zachowały postawę apolityczną, poświęcając się „pracy nad sobą” w oparciu o gromadzony księgozbiór i czasopisma pedagogiczne. Sugerował też, aby przedmiotem ich działań było badanie folkloru, gwary ludowej, a w razie potrzeby nawiązanie na tym polu współpracy z Akademią Umiejętności w Krakowie i Warszawskim Towarzystwem Naukowym. Zalecał prowadzenie badań pedagogicznych nad rozwojem i edukacją dziecka. Na zakończenie wystąpienia z całą stanowczością podkreślił polski charakter seminarium piotrkowskiego ${ }^{14}$.

W przemówieniu inauguracyjnym dyrektora dominowały uwagi u charakterze praktycznym, wynikało $\mathrm{z}$ nich, że praca oświatowa nauczycielki daleko wykraczała poza mury szkoły. Miała ona szerzyć oświatę i kulturę w społeczeństwie, a zwłaszcza w środowisku wiejskim.

Od pierwszych dni funkcjonowania seminarium żeńskiego praca edukacyjna nabrała dużego przyśpieszenia. Szkoła „oddychała już pełną piersią polskości. Władze austriackie, siedzące same w Lublinie nie bardzo mieszały się do spraw Zakładu. Młodzież i skromne grono nauczycielskie rozwinęly gorączkową działalność i praca

13 Tamże, s. 6.

14 Tamże, s. 7-12. 
w Zakładzie potoczyła się wartkim tempem”15. Plan nauczania obejmował na kursie pierwszym 13 przedmiotów a na kursie drugim 14 . Nie prowadzono zajęć z gimnastyki z powodu braku odpowiednio wykwalifikowanego nauczyciela. Szczegółową siatkę godzin i wykaz przedmiotów przedstawia tabela 2.

Tabela 1. Tygodniowy plan godzin Publicznego Seminarium Nauczycielskiego Żeńskiego w Piotrkowie w roku szkolnym $1916 / 1917$

\begin{tabular}{|l|c|c|}
\hline \multirow{2}{*}{ Przedmioty } & \multicolumn{2}{c|}{ Kursy } \\
\cline { 2 - 3 } & I & II \\
\hline Religia & 2 & 2 \\
\hline J. polski & 4 & 4 \\
\hline Pedagogika & - & 2 \\
\hline J. niemiecki & 3 & 3 \\
\hline Historia & 3 & 2 \\
\hline Geografia & 2 & 3 \\
\hline Matematyka & 4 & 4 \\
\hline Przyrodnicze nauki & 3 & 3 \\
\hline Fizyka (chemia w I) & 2 & 3 \\
\hline Rysunki & 2 & 2 \\
\hline Kaligrafia & 1 & 1 \\
\hline Roboty ręczne & 2 & 2 \\
\hline Śpiew (I i II wspólnie 2 godz.) & 2 & 2 \\
\hline Muzyka & 2 & 2 \\
\hline Razem & 32 & 35 \\
\hline
\end{tabular}

Źródło: I Sprawozdanie dyrekcji Publicznego Seminarium Żeńskiego w Piotrkowie za rok szkolny 1916/17, s. 23.

Zajęcia $\mathrm{z}$ seminaryjną młodzieżą prowadzili w języku polskim dobrze wykształceni i posiadający należytą praktykę pedagogiczną nauczyciele. Dyrektor seminarium dr Jan Magiera, czasowo zwolniony przez Radę Szkolną Krajową pismem z dnia 28 września 1916 roku z dotychczasowych obowiązków nauczyciela Gimnazjum V w Krakowie, podjął pracę w Piotrkowie 30 października (za akceptacją RSK i na podstawie decyzji austriackich władz okupacyjnych w Lublinie z 18 października). Uczył języka polskiego i pedagogiki na kursie II, razem 6 godzin tygodniowo.

15 T.S. Grabowski, Jan Magiera pedagog, stowianofil i stowianoznawca polski (1877-1958), „Przegląd Historyczno-Oświatowy” 1962, nr 2, s. 278. 
Nauczycielami seminarium byli:

Stanisław Naszydłowski - kandydat nauk inżynierskich w Leodium (Liege) i absolwent politechniki w Mons na terenie Belgii, nauczyciel stały, powołany na to stanowisko przez Generał-Gubernatorstwo w Lublinie. Gospodarz kursu II uczył j. polskiego, matematyki i fizyki, razem 15 godz. tygodniowo. Opiekował się pomocami dydaktycznymi z fizyki. Nadobowiązkowo prowadził 2 godz. tygodniowo zajęcia $\mathrm{z}$ j. francuskiego.

Aleksander Petrajtys - kandydat filozofii, nauczyciel stały. Gospodarz kursu I uczył historii, geografii, chemii i nauk przyrodniczych, razem 17 godz. tygodniowo. Opiekował się gabinetem przyrodniczym i dość licznymi pomocami dydaktycznymi z historii oraz geografii.

Ludwik Bogobowicz - nauczyciel szkoły miejskiej w Piotrkowie, uczył muzyki i śpiewu oraz prowadził chór szkolny, razem 6 godz. tygodniowo.

Ks. kanonik Zenon Cwilong - zarządca kościoła popijarskiego, uczył religii rzymskokatolickiej w seminarium i szkole ćwiczeń, razem 8 godz. tygodniowo.

W szkole ćwiczeń pracowały:

Zofia Pfauówna - dotychczasowa nauczycielka tymczasowa w szkole wydziałowej im. św. Anny we Lwowie. Prowadziła klasę I, ponadto uczyła języka niemieckiego i robót ręcznych w seminarium nauczycielskim, razem 25 godz. tygodniowo.

Helena Pizłówna - dotychczasowa nauczycielka tymczasowa w szkole wydziałowej XLIV w Krakowie. Prowadziła klasę II, ponadto uczyła rysunków i kaligrafii w seminarium nauczycielskim, razem 27 godz. tygodniowo.

W następnych latach przydział przedmiotów i zadań ulegał zmianom. Nietrudno zauważyć, że podstawową kadrę pedagogiczną seminarium tworzyli nauczyciele przybyli z Galicji, posiadający praktykę pedagogiczną i odpowiednie kwalifikacje.

Już w pierwszym roku istnienia seminarium jego nauczyciele mieli dostęp do „Czasopisma Pedagogicznego”, „Ruchu Pedagogicznego” i „Szkoły Polskiej”. Biblioteka nauczycielska liczyła 48 dzieł w 50 tomach, a biblioteka uczniowska 84 dzieła w 114 tomach. Dary książkowe napłynęły z lwowskiej Książnicy Polskiej, od Kazimierza Jakubowskiego ze Lwowa, Gimnazjum V z Krakowa i redakcji „Wiadomości 
Polskich”. Pewną część wyposażenia seminarium stanowiły dary grona nauczycielskiego. Istniały 3 gabinety: przyrodniczy, fizyczny, rysunkowy i robót ręcznych oraz bogaty zbiór pomocy dydaktycznych. Prężną pracę rozwijał w szkole chór złożony z uczennic i kandydatek do seminarium nauczycielskiego, uczęszczających na kurs przygotowawczy.

Szkoła troszczyła się o sytuację materialną seminarzystek. W roku szkolnym 1916/1917 7 uczennic pobierało miesięczne stypendia po 30 koron, a 4 po 25 koron. Łącznie w okresie trwania roku szkolnego wypłacono dziewczętom 2300 koron. Ponadto uczennice mające szczególnie trudne warunki materialne i potrzeby losowe mogły liczyć na wsparcie ze strony stworzonego przez nauczycieli funduszu w wysokości 100 koron pod nazwą „Pomoc Koleżeńska”

Kadra pedagogiczna seminarium nauczycielskiego żeńskiego, prowadząc wytężoną pracę dydaktyczno-wychowawczą z uczennicami wykazywała zainteresowanie odpowiednim naborem kandydatek na pierwszy kurs w 2017 roku. W tym celu, zgodnie ze zwyczajem i obowiązującym prawem galicyjskim ${ }^{17}$, grono nauczycielskie zorganizowało od 12 grudnia 1916 do 10 czerwca 1917 roku kurs przygotowawczy dla kandydatek do seminarium. Zajęcia trwały 2 godziny dziennie po południu w każdym dniu roboczym. Naukę koncentrowano głównie na j. polskim, matematyce i j. niemieckim. W zajęciach uczestniczyły początkowo 42 kandydatki. Do końca kursu dotrwało 28 osób. Egzamin wstępny do seminarium w dniu 20 czerwca złożyło pomyślnie 16 dziewcząt. Należy dodać, że kurs ten miał charakter prywatny i był bezpłatny ${ }^{18}$.

Austriackie władze wojskowe bacznie śledziły postępy w powołanych przez nie 6 seminariach nauczycielskich i szkołach ćwiczeń. Świadczy o tym wnikliwe, statystyczne zestawienie zbiorcze na ten temat, sporządzone na koniec roku szkolnego 1916/1917 ${ }^{19}$.

16 I Sprawozdanie dyrekcji Publicznego Seminarium Żeńskiego w Piotrkowie za rok szkolny 1916/17, dz. cyt., s. 16, 17, 18, 20.

17 Przepisy o ksztatceniu nauczycieli oraz o uzdolnieniu do nauczania w szkotach ludowych w Galicji, dz. cyt., s. 6-10.

18 I Sprawozdanie dyrekcji Publicznego Seminarium Żeńskiego w Piotrkowie za rok szkolny 1916/17, dz. cyt., s. 14, 20.

19 APPT, KPP, sygn. 303. C. i k. Generalne Gubernatorstwo Wojskowe w Polsce. Wykazy statystyczne dotyczace publicznego szkolnictwa po poczatkowego i średniego w r. szk. 1916/7 i 1917/8. 


\section{Ku wolnej Polsce. Drugi rok działalności}

Nowy rok szkolny1917/1918 rozpoczęto 4 września. W pierwszych miesiącach 1917 roku seminarium piotrkowskie, podobnie jak inne szkoły nauczycielskie, stało się przedmiotem zainteresowań, a następnie podlegało Departamentowi WRiOP, ustanowionemu na posiedzeniu Wydziału Wykonawczego Tymczasowej Rady Stanu Królestwa Polskiego w dniu 23 stycznia 1917 roku, a później utworzonemu 7 grudnia 1917 roku Ministerstwu WRiOP20.

W dniu 1 grudnia 1917 roku szkoła uzyskała nazwę: Państwowe Seminarium Nauczycielskie Żeńskie w Piotrkowie. Otrzymała godło polskie. Nauczyciele złożyli przyrzeczenie sumiennego wypełniania obowiązków. Były to niezwykle doniosłe, wzruszające chwile w życiu społeczności seminaryjnej ${ }^{21}$.

Nastąpiły niezbędne zmiany w organizacji procesu nauczania. W tygodniowym planie godzin umieszczono na III kursie kolejny przedmiot zawodowy seminarium nauczycielskiego (obok istniejącej od drugiej klasy pedagogiki), a mianowicie lekcje praktyczne z omówieniem, kontynuowano śpiew jako teorię muzyki i grę na skrzypcach. Wprowadzono na każdym kursie po 1 godzinie somatologii ${ }^{22}$. W drugim roku istnienia seminarium można było wyodrębnić w planie godzin III kursu trzy wyraźne grupy przedmiotów: pedagogiczne, czyli zawodowe, ogólnokształcące i artystyczne. Do przedmiotów artystycznych zaliczano także prowadzone na wysokim poziomie rysunki ${ }^{23}$. Pierwsza i trzecia grupa przedmiotów odróżniała seminarium nauczycielskie od szkoły gimnazjum. Przedmioty te siłą rzeczy uszczuplały jednak liczbę godzin prze-

20 S. Konarski, Dzieje szkolnictwa w b. Królestwie Kongresowym 1915-1918, Kraków 1923, s. 255, 256; F. Śliwiński, Organizacja wtadz szkolnych i szkolnictwa wszystkich stopni w Polsce Ludowej, Warszawa-Lwów 1929, s. 3; por. Dziennik Praw z 1 lutego 1918r, nr 1, poz. 1. Ministerstwo WRiOP zarząd nad szkolnictwem, w tym i nad seminariami nauczycielskimi przejęło 3 stycznia $1918 \mathrm{r}$.

21 I(II) Sprawozdanie dyrekcji Państworwego Seminarium Nauczycielskiego Żeńskiego w Piotrkowie za rok szkolny 1917/18, dz. cyt., s. 21.

22 Tamże, s. 48.

23 H. Pizło-Petrajtysowa, Studia z natury. Kwiaty w nauce rysunków w szkole żeńskiej, w: I(II) Sprawozdanie dyrekcji Państwowego Seminarium Nauczycielskiego Żeńskiego w Piotrkowie za rok szkolny 1917/18, dz. cyt., s. 3-18. 
znaczonych na kształcenie ogólnokształcące ${ }^{24}$. Plan zajęć i wykaz przedmiotów w seminarium i szkole ćwiczeń zawiera tabela 2 .

Tabela 2. Tygodniowy plan godzin Państwowego Seminarium Nauczycielskiego Żeńskiego i Szkoły Ćwiczeń w Piotrkowie w roku szkolnym $1917 / 1918$

\begin{tabular}{|c|c|c|c|c|c|c|}
\hline \multirow[t]{2}{*}{ Przedmioty } & \multicolumn{3}{|c|}{$\begin{array}{c}\text { Kursy } \\
\text { seminarium }\end{array}$} & \multicolumn{3}{|c|}{$\begin{array}{l}\text { Klasy szkoły } \\
\text { ćwiczeń }\end{array}$} \\
\hline & I & II & III & 1. & 2. & 3. \\
\hline Religia & 2 & 2 & 2 & 2 & 2 & 2 \\
\hline Pedagogika & - & 2 & 2 & - & - & - \\
\hline Lecje praktyczne z omówieniem & - & - & 2 & - & - & - \\
\hline J. polski & 4 & 4 & 4 & 9 & 12 & 9 \\
\hline J. niemiecki & 3 & 3 & 3 & - & - & 3 \\
\hline Dzieje powszechne & 2 & 2 & 2 & - & - & - \\
\hline Geografia & 2 & 2 & 2 & - & - & - \\
\hline Przyrodnicze nauki & 2 & 2 & 2 & - & - & - \\
\hline Somatologia & 1 & 1 & 1 & - & - & - \\
\hline Fizyka (chemia) & 2 & 2 & 2 & - & - & - \\
\hline Matematyka (rachunki) & 4 & 4 & 4 & 3 & 3 & 3 \\
\hline Rysunki & 2 & 2 & 2 & - & 1 & 1 \\
\hline Kaligrafia & 1 & (1) & (1) & - & 1 & 1 \\
\hline Śpiew (teoria muzyki) & 1 & 1 & 1 & 2 & 1 & 1 \\
\hline Gra na skrzypcach & 2 & 2 & 2 & - & - & - \\
\hline Gimnastyka & 2 & 2 & 2 & 1 & 1 & 1 \\
\hline Roboty ręczne kobiece & 2 & 2 & 2 & - & 1 & 1 \\
\hline Czytanie (i pisanie) & - & - & - & - & 1 & 2 \\
\hline Razem & 32 & 34 & 36 & 17 & 23 & 24 \\
\hline
\end{tabular}

Źródło: I(II) Sprawozdanie dyrekcii Państwowego Seminarium Nauczycielskiego Żeńskiego w Piotrkowie za rok szkolny 1917/18, s. 48.

Ważnym uzupełnieniem edukacji nauczycielskiej, realizowanej poza planem godzin, był chór prowadzony na trzy głosy, który ćwiczył co najmniej godzinę tygodniowo. Repertuar obejmował pieśni

24 Por. K. Konarski, Dzieje szkolnictwa w b. Królestwie Kongresowym 1915-1918, dz. cyt., s. $198 . Z$ tego też powodu uniwersytety nie przyjmowały na studia kandydatów z maturą seminaryjną. Fakt ten miał poważne konsekwencje zarówno dla prestiżu seminariów, jak i dalszej nauki ich absolwentów, ponieważ uniemożliwiał bezpośrednie podejmowanie studiów akademickich. 
kościelne i świeckie. Należały do nich m.in. Wspomnienie, Witaj majowa jutrzenko, Warszawianka, Patrz Kościuszko, Rota ${ }^{25}$.

Wydłużenie o jeden rok procesu nauczania w seminarium, jak również w szkole ćwiczeń, spowodowało zwiększenie liczby godzin dydaktycznych w tych placówkach i w konsekwencji wzrost zapotrzebowania na kadrę pedagogiczną. Obok dotychczas pracujących, nowo zatrudnionymi nauczycielami w roku szkolnym 1917/1918 zostali:

Jan Władysław Celejowski - nauczyciel pomocniczy, uczył muzyki, śpiewu i prowadził chór szkolny, razem 11 godz. tygodniowo.

Henryk Kobus - dr nauk medycznych, wykładał somatologię.

H. Pizło-Petrajtysowa - gospodyni kursu I, uczyła j. niemieckiego, rysunków, robót ręcznych i kaligrafii, razem 24 godz. tygodniowo. Ponadto opiekowała się harcerstwem.

W szkole ćwiczeń obok Z. Pfauówny, która była wychowawczynią klasy II i uczyła w seminarium j. polskiego oraz nadobowiązkowo j. francuskiego (razem 25+4 godz. tygodniowo), zatrudniono dwie nowe nauczycielki:

Mieczysława Suchecka została wychowawczynią klasy III (22 godz. tygodniowo), a od półrocza prowadziła także $\mathrm{w}$ zastępstwie klasę I (razem 28 godz. tygodniowo). Ponadto opiekowała się biblioteką dla uczennic seminarium i księgozbiorem dziecięcym dla szkoły ćwiczeń.

Zofia Izabela Wiśniewska objęła wychowawstwo klasy I i prowadziła gimnastykę w seminarium. Zajęcia te realizowała jednak tylko w pierwszym półroczu, ponieważ zachorowała na tyfus i po wyleczeniu otrzymała urlop do końca roku szkolnego ${ }^{26}$.

W seminarium coraz silniej zaznaczało swoją obecność harcerstwo. Została zorganizowana drużyna im. Emilii Plater, w skład której wchodziły 3 zastępy, każdy liczący po 10 harcerek. Na cotygodniowych zbiórkach zapoznawano się z historią ruchu skautowego, „ćwiczono się w mustrze, gimnastyce i rytmicznym oddychaniu, nadto uprawiano gry skautowe; w pogadankach zaś omawiano cnoty harcerskie, jak rycerskość, pracowitość, wytrwałość, miłość ojczyzny, miłość przyrody itd."27.

25 I(II) Sprawozdanie dyrekcji Państwowego Seminarium Nauczycielskiego Żeńskiego w Piotrkowie za rok szkolny 1917/18, dz. cyt., s. 34.

26 Tamże, s. 26, 27.

27 Tamże s. 35. W następnych latach, zwłaszcza gdy dyrektorem seminarium była w latach 1928-1936 Celestyna Orlikowska (ur. 24 czerwca 1892 r. 
Uczennice opiekowały się ogródkiem szkolnym, uczestniczyły w życiu Towarzystwa Krajoznawczego. Chętnie brały udział w wycieczkach do huty szkła ozdobnego „Hortensja” na terenie miasta, do pobliskiego Wolborza, czy też Dąbrowy nad Czarną w powiecie opoczyńskim, gdzie zwiedzily interesującą wytwórnię garnków glinianych. Grupa dziewcząt wystawiła kilka przedstawień teatralnych, m.in. Barbary Żulińskiej i J. Jaworskiej Modlitwę św. Jadwigi. Szczególną popularnością cieszyły się wieczory baśni i inscenizacje utworów M. Konopnickiej Na jagody, Wędrowniczek i Kopciuszek, zorganizowane przez seminarzystki dla dzieci ze szkoły ćwiczeń i innych szkół miejskich. W seminarium uroczyście obchodzono wraz z całym społeczeństwem w dniu 15 października 1917 roku setną rocznicę zgonu naczelnika T. Kościuszki, czczono też kolejną rocznicę listopadową i wygłoszono cykl odczytów dotyczących powstania styczniowego. W obchodach 3 Maja szczególnie wyróżniły się pięknymi deklamacjami dzieci ze szkoły ćwiczeń. One też przygotowały po kierownictwem Z. Pfauówny złożone $z$ recytacji i pląsów widowiska sceniczne utworów literackich H. Sienkiewicza. Z kolei z inicjatywy H. Pizło-Petrajtysowej zorganizowano na koniec roku szkolnego wystawę robót i rysunku, którą zwiedziło kilkuset mieszkańców Piotrkowa ${ }^{28}$.

W roku szkolnym 1917/1918 na pierwszym, drugim i trzecim kursie rozpoczęły naukę 62 uczennice seminarium żeńskiego i 81 uczniów trzech klas szkoły ćwiczeń. Na koniec roku szkolnego było 58 seminarzystek i 79 uczniów szkoły wzorowej. Wiek uczennic seminarium był dosyć zróżnicowany i kształtował się od 16 do 24 roku życia. Zdecydowana większość była wyznania rzymskokatolickiego. Wszystkie dziewczęta urodziły się w Królestwie Polskim, 53 miały rodziców Piotrkowie. Struktura społeczna uczniów przedstawiała się w sposób następujący: dzieci właścicieli gospodarstw i innych posiadłości było 10, rzemieślników i osób zatrudnionych w przemyśle - 17, kupców i kramarzy - 8, pracowników kolei - 8, urzędników różnych szczebli -7 . Pozostałe uczennice wywodziły się z rodzin wyrobników, sług i innych. Nadobowiązkową naukę języka francuskiego pobierało

w Fedorówce na Podolu, zm. 6 czerwca 1977 r. w Warszawie, dr nauk przyrodniczych, absolwentka Uniwersytetu Warszawskiego), praca harcerska osiągnęła wysoki poziom. Orlikowska była drużynową, opiekunką drużyny, zorganizowała też Hufiec harcerek w Piotrkowie.

28 Tamże, s. 24. 
28 dziewcząt. Promocję na następny kurs z wynikiem chlubnym uzyskało 8 uczennic. Promocji nie otrzymały 4 osoby, a do egzaminu poprawkowego, bądź uzupełniającego, zakwalifikowano 12 dziewcząt.

Wiek uczniów szkoły ćwiczeń wynosił od 7 do 14 lat. Najwięcej dzieci miało od 8 do 10 lat. $Z$ wyjątkiem dwojga, wszyscy byli z Piotrkowa. Dominowały dzieci właścicieli gospodarstw, kupców i kramarzy oraz urzędników, ale kilkunastu uczniów wywodziło się spośród mniej zamożnych rodzin. Wyraźną większość stanowily dziewczęta. Dwoje dzieci było wyznania greckokatolickiego, czworo ewangelicko-augsburskiego, troje mojżeszowego, a pozostali rzymskokatolickiego ${ }^{29}$.

W roku szkolnym 1917/1918 33 seminarzystki otrzymywały miesięczne stypendia o łącznej kwocie 7275 koron $^{30}$. Niektóre z nich znajdowały się w szczególnie trudnych warunkach. Pomoc finansową uczennicom o niższym statusie materialnym starała się nieść złożona z seminarzystek Wzajemna Pomoc Uczennic. Wybrany został zarząd tej organizacji w składzie: przewodnicząca Marianna Całówna, skarbniczka Rozalia Wagnerówna, rewizorka Antonina Kluczyńska. 41 członkiń tej organizacji płaciło składkę miesięczną po 30 halerzy, 5 - po 40 halerzy, 4 - po 50 halerzy, 2 - po 1 koronie. Grono nauczycielskie wniosło do Wzajemnej Pomocy Uczennic 100 koron wkładu z tytułu członkostwa wieczystego, a Komenda Powiatowa w Piotrkowie przekazała zapomogę w wysokości 500 koron $^{31}$.

Celem pozyskania ewentualnych środków finansowych i wsparcia materialnego przewodnicząca Wzajemnej Pomocy Uczennic M. Całówna i kurator tej organizacji z ramienia grona nauczycielskiego S. Naszydłowski zwrócili się do Generał-Gubernatorstwa w Lublinie z prośbą „o pomoc, a szczególnie pomoc w naturaliach, jak materiały na ciepłą odzież, bieliznę, kawę lub herbatę dla herbaciarni szkolnej itp. ${ }^{32}$. W odpowiedzi na tę prośbę Generał-Gubernatorstwo przyznało jednorazową zapomogę w kwocie 300 koron $^{33}$.

29 Tamże, s. 44, 45.

30 Tamże.

31 Tamże, s. 36.

32 APPT, KPP, sygn. 302, Pismo M. Całusówny i S. Naszydłowskiego z 24 listopada 1917 r. do Generał-Gubernatorstwa w Lublinie z prośba o wsparcie materialne dla Wzajemnej Pomocy Uczennic.

33 Tamże. Odpis pisma Generał-Gubernatorstwa w Lublinie z 9 lutego 1918 r., zawiadamiającego o przyznaniu zapomogi dla Wzajemnej Pomocy Uczennic. 
$\mathrm{Z}$ początkiem roku szkolnego otwarto, $\mathrm{w}$ ramach działalności Wzajemnej Pomocy Uczennic, sklep z przyborami szkolnymi i podręcznikami. Jego kierowniczką została uczennica Józefa Bronisława Zynerówna. Sprzedaż i wypożyczanie książek prowadziła Kazimiera Śledzińska. Dochód ze sprzedaży zasilił fundusz organizacji. Pewne kwoty pieniężne uzyskano również z tytułu dobrowolnych kwot wpłacanych przez osoby oglądające przedstawienia szkolne, organizowane przez dziewczęta pod kierunkiem Z. Pfauówny. Pragnąc pomóc Wzajemnej Pomocy Uczennic w pozyskaniu funduszy grono nauczycielskie zorganizowało odpłatnie cztery odczyty, za które uzyskano 180 koron. Tytuły referatów były następujące: J. Magiera - J.I. Kraszerwski, H. Petrjtysowa - A. Grottger na tle jego epoki, S. Naszydłowski - Kooperatywa, jej idea i rozwoój, Z. Pfauówna O Tatrach.

Wiele inicjatywy wykazała organizacja uczennic w sprawie uruchomienia internatu dla dziewcząt spoza Piotrkowa. Na trzecim walnym zebraniu dokonano wyboru nowych władz Wzajemnej Pomocy Uczennic na rok szkolny 1918/1919. Przewodnicząca została Aleksandra Żubrówna, sekretarką Helena Stefańska, skarbniczką Lucyna Wojtasiewiczówna, kierowniczką sklepu Eugenia Zarzycka, prowadzącą kawiarnię Antonina Kluczyńska ${ }^{34}$.

Dyrekcja i grono nauczycielskie ściśle współpracowało z rodzicami. W omawianym roku szkolnym zorganizowano 6 zebrań ogólnych $\mathrm{z}$ rodzicami oraz utrzymywano liczne kontakty indywidualne. Tematem zebrań były sprawy wychowawcze i materialne szkoły oraz uczennic. Dyrekcja seminarium wyrażała wielokrotnie słowa podziękowań wszystkim instytucjom i osobom, które w jakikolwiek sposób wspierały zakład kształcenia nauczycieli ${ }^{35}$.

Działalność dydaktyczna i wychowawcza piotrkowskiego seminarium wzbudziła duże zainteresowanie warszawskich władz oświatowych. Jego dorobek starano się wykorzystać w pracach nad sformułowaniem nowego modelu seminarium nauczycielskiego. 9 lutego 1918 roku w zakładzie przebywał wizytator K. Morawski z Sekcji II Szkolnictwa Średniego, a w dniach 23-25 tegoż miesiąca

34 I(II) Sprawozdanie dyrekcji Państwowego Seminarium Nauczycielskiego Żeńskiego w Piotrkowie za rok szkolny 1917/18, dz. cyt., s. 35-37.

35 Tamże, s. 22. 
szkołę odwiedził Konrad Chmielewski, inspektor Wydziału Kształcenia Nauczycieli Departamentu Oświecenia Ministerstwa WRiOP. W trakcie pobytu inspektor przysłuchiwał się zajęciom hospitacyjnym i ich omówieniu, a także wizytował szkołę ćwiczeń. Wyrażał też zainteresowanie kwalifikacjami kadry pedagogicznej ${ }^{36}$.

W dniu 6 maja 1918 roku Ministerstwo WRiOP wyznaczyło J. Magierę na swojego delegata i przewodniczącego egzaminu końcowego 16 uczennic Wyższych Kursów Pedagogicznych Żeńskich II Koła Polskiej Macierzy Szkolnej w Piotrkowie ${ }^{37}$. Kursy te pod kierownictwem znanej w okresie międzywojennym piotrkowianki (późniejszej dyrektorki Seminarium Nauczycielskiego Żeńskiego w Chełmie, propagatorki systemu daltońskiego w Polsce) dr Jadwigi Młodowskiej rozpoczęły działalność 15 września 1917 roku. Program zajęć kładł duży nacisk na poznanie wiadomości z zakresu zagadnień pedagogicznych i psychologicznych ze szczególnym uwzględnieniem metodyki nauczania poszczególnych przedmiotów. O potrzebie zorganizowania tej formy edukacji nauczycieli świadczył fakt, że w krótkim czasie zgłosiła się znaczna liczba słuchaczek ${ }^{38}$.

W dniu 17 czerwca dobiegł końca rok szkolny 1917/1918. Całoroczny trud pedagogiczny i uczniowski zwieńczony został po raz pierwszy uroczystym rozdaniem świadectw z orłem polskim i odśpiewaniem pieśni Gaudeamus oraz Pożegnanie ze szkotq. Podczas wakacji nauczyciele seminarium udzielili wsparcia piotrkowskiemu środowisku nauczycielskiemu. Na podstawie bowiem uchwały Rady Szkolnej Okręgu Piotrkowskiego otwarto w dniu 15

36 Tamże, s. 21, 22.

37 Tamże, s. 21, 22, 24.

38 APPT, zespół: Materiały dotyczące Polskiej Macierzy Szkolnej 1906-1917, sygn. 17, Plakaty informujące o otwarciu Wyższych Kursów Nauczycielskich Żeńskich w Piotrkowie; Kronika pedagogiczna, „Ruch Pedagogiczny” 1918, rocznik V, s. 143, 144. Wyższe Kursy istniały w Piotrkowie w latach 1917-1919. Nauka w nich trwała jeden rok. Na rok szkolny 1918/1919 zapisało się 25 kandydatek. Zostały one zamknięte w związku z przygotowaniem reformy seminariów nauczycielskich. Przy Wyższych Kursach otwarto komplet wzorowy, realizujący zajęcia oparte na elementarzu Mariana Falskiego, pogadanki religijne, przyrodnicze i o rzeczach, zabawy ruchowe połączone ze śpiewem, slojd i modelowaniem w glinie. Zapisy na pierwszy kurs i komplet przyjmowano w siedzibie Zarządu II Koła PMS w Piotrkowie przy ul. Rokszyckiej 16. 
lipca 1918 roku, finansowane przez Ministerstwo WRiOP, czterotygodniowe obowiązkowe kursy wakacyjne dla nauczycieli szkół elementarnych z okręgu piotrkowskiego. Wśród wykładowców kursów byli nauczyciele seminaryjni ${ }^{39}$.

\section{U progu niepodległości. Trzeci rok nauki}

Nowy rok szkolny 1918/1919 rozpoczął się 2 września 1918 roku, na kilka zaledwie miesięcy przed odzyskaniem przez Polskę upragnionej niepodległości. Fakt ten wywarł zasadniczy wpływ na kierunki pracy wychowawczej, a zwłaszcza patriotycznej szkoły. Zarówno seminarium nauczycielskie, jak i szkoła ćwiczeń realizowały już naukę w ciągu 4 lat ${ }^{40}$. Na ostatnim kursie kładziono duży nacisk na przygotowanie do zawodu. Plan nauczania przedmiotów pedagogicznych obejmował 7 godzin tygodniowo ${ }^{41}$. Przedmiotami nadobowiązkowymi były j. francuski i gra na fisharmonii. Nabierał znaczenia chór szkolny. Piotrkowskie seminarium dzieliło się doświadczeniami i pozostawało w ścisłym kontakcie w kwestiach programowych i metodycznych (hospitacje zajęć, wymiana konspektów lekcyjnych), co było bardzo istotne dla doskonalenia procesu nauczania, z trzema bratnimi zakładami: żeńskim w Lublinie i męskimi w Kielcach, a zwłaszcza w Jędrzejowie, którym kierował wysoce życzliwy dla Piotrkowa dyrektor J. Gancarczyk. Doskonalono plan (przejściowy) i zakres nauczania, wprowadzając szereg nowości, zwłaszcza w przedmiotach przyrodniczych $^{42}$. Bliższe informacje na temat siatki godzin w tym roku szkolnym zawiera tabela 3.

39 APPT, Komenda Powiatowa w Piotrkowie, sygn. 302, Pismo Rady Szkolnej Okręgu Piotrkowskiego z 26 czerwca 1918 r. do Wydziału Wykonawczego Sejmiku Powiatowego w sprawie wsparcia materialnego kursów.

40 I(II) Sprawozdanie dyrekcji Państwowego Seminarium Nauczycielskiego Żeńskiego w Piotrkowie za rok szkolny 1917/18, dz. cyt., s. nlb.

41 Przepisy o kształceniu nauczycieli oraz o uzdolnieniu do nauczania w szkotach ludowych w Galicji, dz. cyt., s. 52.

42 A. Matusiakowa, Przyczynki do badań nad rozwojem szkolnictwa nauczycielskiego w Piotrkowie Trybunalskim. Dokumenty walki mtodych Ziemi Piotrkowskiej z okupantem hitlerowskim w latach 1939-1945, dz. cyt., s. 26, 29. 


\begin{tabular}{|c|c|c|c|c|c|}
\hline \multirow{2}{*}{ Przedmioty } & \multicolumn{4}{|c|}{ Kursy } & \multirow{2}{*}{ Uwagi } \\
\hline & I & II & III & IV & \\
\hline Religia & 2 & 2 & 2 & 2 & - \\
\hline Pedagogika & - & 2 & $3 / 2$ & 2 & $\begin{array}{c}\text { I półrocze } \\
3 \text { godz./ || -2 }\end{array}$ \\
\hline Lekcja praktyczna & - & - & $-/ 1$ & 2 & $\begin{array}{l}\text { Il półrocze } \\
1 \text { godz. }\end{array}$ \\
\hline $\begin{array}{l}\text { Metodyka } \\
\text { specjalna }\end{array}$ & - & - & - & 3 & - \\
\hline J. polski & 5 & 4 & 4 & 5 & - \\
\hline J. niemiecki & 3 & 3 & 3 & 3 & - \\
\hline Dzieje powszechne & 2 & 2 & 2 & 2 & - \\
\hline Geografia & 2 & 2 & 2 & $2 / 3$ & $\begin{array}{c}\text { | półrocze } \\
2 \text { godz./ || -3 }\end{array}$ \\
\hline Matematyka & 4 & 3 & 4 & 2 & - \\
\hline $\begin{array}{l}\text { Nauki } \\
\text { przyrodnicze }\end{array}$ & $3 / 2$ & 3 & 2 & 2 & $\begin{array}{c}\text { I półrocze } \\
3 \text { godz./ || -2 }\end{array}$ \\
\hline Higiena & - & - & - & 1 & - \\
\hline Somatologia & $-/ 1$ & - & - & - & $\begin{array}{l}\text { Il półrocze } \\
1 \text { godz. }\end{array}$ \\
\hline Chemia & 2 & - & - & - & - \\
\hline Fizyka & - & 2 & 2 & 2 & - \\
\hline Rysunki & 2 & 2 & 2 & 2 & - \\
\hline $\begin{array}{l}\text { Śpiew } \\
\text { i teoria muzyki }\end{array}$ & 1 & 1 & 1 & - & Zajęcia łączone \\
\hline Gra na skrzypcach & 4 & 4 & 2 & 2 & - \\
\hline Kaligrafia & 1 & - & - & - & - \\
\hline Roboty ręczne & 4 & 4 & 2 & 2 & Zajęcia łączone \\
\hline Gimnastyka & 2 & 2 & 2 & - & Zajęcia łączone \\
\hline Razem & $37 / 37$ & 36 & $33 / 33$ & $34 / 35$ & - \\
\hline
\end{tabular}

Tabela 3.

Tygodniowy plan godzin Państwowego Seminarium Nauczycielskiego Żeńskiego w Piotrkowie w roku szkolnym $1918 / 1919$

Źródło: A. Matusiakowa, Przyczynki do badań nad rozwojem szkolnictwa nauczycielskiego w Piotrkowie Trybunalskim. Dokumenty walki młodych Ziemi Piotrkowskiei z okupantem hitlerowskim w latach 1939-1945, s. 27.

Zadania dydaktyczno-wychowawcze realizowało 13 nauczycieli. Powołano też etat sekretarza szkoły ${ }^{43}$. W marcu 1919 roku seminarium odwiedził minister WRiOP A. Ponikowski, który przekazał

43 Tamże, s. 26. 
roczne stypendium dla dwóch uczennic w wysokości po 400 zł. W roku szkolnym 1918/1919 udało się pozytywnie zakończyć starania o uruchomienie internatu przy ul. 3 Maja 16, który później jeszcze dwukrotnie zmieniał swoją siedzibę ${ }^{44}$.

Wielkim przeżyciem dla uczennic i nauczycieli była pierwsza matura w seminarium. Egzamin pisemny odbył się w dniach 4-7 czerwca 1919 roku, natomiast ustny 11 i 12 tegoż miesiąca. Przewodniczącym komisji egzaminacyjnej był delegat Ministerstwa WRiOP, przyjaciel piotrkowskiego zakładu, wizytator K. Chmielewski. Pierwszymi absolwentkami zostały: Branicówna Ruchla Laja, Całówna Marianna, Dąbrowska Helena, Lewińska Stefania Paulina, Śledzińska Kazimiera, Szafnicka Janina Władysława, Żubrówna Aleksandra. Ponadto w trybie eksternistycznym egzamin dojrzałości zdali: Dymkowska Eugenia Delfina, Jeżewska Maria, Tazbir Maksymilian ${ }^{45}$.

W 1920 roku wojna polsko-bolszewicka spowodowała przerwanie działalności seminarium. Budynek przeznaczono na szpital wojskowy. Nauczyciele i młodzież uczestniczyli w pracach filantropijnych. Seminarzystki pod kierunkiem nauczycielek ofiarnie wypełniały zadania pielęgniarek i sanitariuszek, tworząc „brygadę seminarium”. Wznowienie pięcioletniej już edukacji miało w trudnych warunkach powojennych charakter wysoce rozwojowy - świadczą o tym chociażby dane statystyczne dotyczące seminarium z września 1921 roku $^{46}$.

\section{Uwagi końcowe}

Państwowe Seminarium Nauczycielskie Żeńskie w Piotrkowie, mimo że powstało formalnie na podstawie decyzji austriackich władz wojskowych, to jednak od samego od samego początku swego istnienia było na wskroś polskie. Odznaczało się patriotyczną atmosferą wychowawczą, spełniało ważną funkcję kulturotwórczą w środowisku. Plan

${ }_{44}$ Tamże, s. 24, 28.

45 Tamże, s. 25.

46 APPT, zespól: Akta Miasta Piotrkowa, cz. III, sygn. 10995, Akta Magistratu miasta Piotrkowa o statystyce szkolnej. Rozpoczęto 28 września 1921r. We wrześniu 1921r. seminarium liczyło 147 uczennic, w tym w klasie I - 42, II -31 , III - 26, IV - 25, V - 23. Zajmowało 5 sal szkolnych. Na etatach zatrudniono 8 nauczycieli, w tym 4 kobiety. Ponadto część nauczycieli pracowała po kilka godzin tygodniowo. 
godzin i program nauczania, początkowo mocno zbliżony do programu seminariów galicyjskich, z każdy rokiem coraz bardziej stawał się od nich odmienny, przybierał charakter przejściowy, by ulec istotnej zmianie po wydaniu dekretu z lutego 1919 roku O ksztatceniu nauczycieli szkót powszechnych w państwie polskim ${ }^{47}$, wprowadzającym pięcioletnie seminaria nauczycielskie i ukazaniu się w 1921 roku programu nauczania w tych szkołach ${ }^{48}$. W niepodległej Polsce następował szybki rozwój seminarium. W pracy edukacyjnej uwzględniało ono także dyspozycje Dekretu o obowiqazku szkolnym ${ }^{49}$ oraz Ustawe o zaktadaniu i utrzymywaniu publicznych szkót porwszechnych ${ }^{50}$.

W 1925 roku Państwowe Seminarium Nauczycielskie Żeńskie otrzymało imię Królowej Jadwigi. Swoją działalność zakończyło w 1936 roku. W okresie 20 lat istnienia pracowało w nim 54 nauczycieli, którzy wykształcili 397 wykwalifikowanych nauczycielek szkół powszechnych ${ }^{51}$.

Piotrków Trybunalski jako ośrodek kształcenia nauczycieli trwa nieprzerwanie od 100 lat do dnia dzisiejszego.

\section{BIBLIOGRAFIA}

Źródła archiwalne

Archiwum Państwowe w Piotrkowie Trybunalskim:

zespół: Komenda Powiatowa w Piotrkowie, sygn. sygn. 302, 303.

zespół: Akta Miasta Piotrkowa, cz. III, sygn. 10995.

Źródła drukowane:

Dziennik Praw, Drukarnia Rządowa przy Komisji Rządowej Oświecenia Publicznego, Warszawa 1866, t. 64, nr 209.

Dziennik Praw z 1 lutego 1918 r, nr 1, poz. 1.

Dz. Urz. MWRiOP 1919, nr 2, poz. 2, 3; 1921, nr 22, poz. 3; 1922, nr 12, poz. 110 .

47 Dz. Urz. MWRiOP 1919, nr 2, poz. 3.

48 Program nauki w państwowych seminariach nauczycielskich, Warszawa 1921, por. Dz. Urz. MWRiOP 1921, nr 22, poz. 3.

49 Dz. Urz. WRiOP 1919, nr 2, poz. 2.

50 Dz. Urz. MWRiOP 1922, nr 12, poz. 110.

51 A. Matusiakowa, Przyczynki do badań nad rozwojem szkolnictwa nauczycielskiego w Piotrkowie Trybunalskim. Dokumenty walki mtodych Ziemi Piotrkowskiej z okupantem hitlerowskim w latach 1939-1945, dz. cyt., s. 38. 
Grzybek W., Magiera Jan Franciszek, w: Polski stownik biograficzny, t. XIX, Kraków 1974.

Magiera J., Nauczycielka na wsi, w: I Sprawozdanie dyrekcji Publicznego Seminarium Żeńskiego w Piotrkowie za rok szkolny 1916/17, Drukarnia M. Dobrzańskiego, Piotrków Trybunalski 1917.

I Sprawozdanie dyrekcji Publicznego Seminarium Żeńskiego w Piotrkowie za rok szkolny 1916/17, Drukarnia M. Dobrzańskiego, Piotrków Trybunalski 1917.

I(II) Sprawozdanie dyrekcji Państwowego Seminarium Nauczycielskiego Żeńskiego w Piotrkowie za rok szkolny 1917/18, „Drukarnia Polska” Józefa Waleckiego i Ski, Piotrków Trybunalski 1918.

Pizło-Petrajtysowa H., Studia z natury. Kwiaty w nauce rysunków w szkole żenskiej, w: I(II) Sprawozdanie dyrekcji Państwowego Seminarium Nauczycielskiego Żeńskiego w Piotrkowie za rok szkolny 1917/18, „Drukarnia Polska” Józefa Waleckiego i Ski, Piotrków Trybunalski 1918.

Przepisy o ksztatceniu nauczycieli oraz o uzdolnieniu do nauczania w szkotach ludowych w Galicji, w: Dodatek do Dz. U. c.k. Rady Szkolnej Krajowej, Nakł. c.k. Rady Szkolnej Krajowej, Drukarnia Wł. Łozińskiego, Lwów 1909.

Opracowania

Bednarski S., Upadek i odrodzenie szkót jezuickich w Polsce. Studium z dziejów kultury i szkolnictwa polskiego, Wydawnictwo Księży Jezuitów, Kraków 1933. Reprint wykonało Wydawnictwo WAM w 2003 roku.

Borowiecka M., Jan Magiera 1876-1958, „Pamiętnik Słowiański” 1960, t. X.

Doroszewski J., Zaktady ksztatcenia nauczycieli w województwie lubelskim w latach 1918-939, Lubelskie Towarzystwo Naukowe, Lublin 1999.

Grabowski T. S., Jan Magiera pedagog, stowianofil i stowianoznawca polski (1877-1958), „Przegląd Historyczno-Oświatowy”, 1962, nr 2.

Konarski S., Dzieje szkolnictwa w b. Królestwie Kongresowym 1915-1918, Skład Główny Książnicy Polskiej w Warszawie, Kraków 1923.

Kronika pedagogiczna, „Ruch Pedagogiczny” 1918, rocznik V.

Kucha R., Oświata elementarna w Królestwie Polskim w latach 1864-1914, Krajowa Agencja Wydawnicza, Lublin 1982.

Kulpa J., Ksztatcenie nauczycieli szkót powszechnych w Polsce w latach 1918-1939, Zakład Narodowy im. Ossolińskich, Wrocław 1963.

Majorek Cz., Galicyjskie koncepcje organizacji szkolnictwa pedagogicznego, „Rozprawy z Dziejów Oświaty”, 1968.

Matusiakowa A., Przyczynki do badań nad rozwojem szkolnictwa nauczycielskiego w Piotrkowie Trybunalskim. Dokumenty walki mtodych Ziemi Piotrkowskiej z okupantem hitlerowskim w latach 1939-1945, Nakł. Rodziny i ZNP w Piotrkowie Trybunalskim, Lodź 1993. 
Meissner A., Spór o duszę polskiego nauczyciela. Spoteczeństwo galicyjskie wobec problemów nauczycieli, Wydawnictwo Wyższej Szkoły Pedagogicznej, Rzeszów 1999.

Piechnik L., Początki seminariów nauczycielskich w Polsce w wieku XVI, w: Z dziejów szkolnictwa jezuickiego w Polsce. Wybór artykutów, oprac. J. Paszenda SJ, Wydawnictwo WAM, Kraków 1994.

Śliwiński F., Organizacja wtadz szkolnych $i$ szkolnictwa wszystkich stopni w Polsce Ludowej, „Książnica - Atlas”, Warszawa-Lwów 1929.

\section{ADRES DO KORESPONDENCJI}

Dr hab. Witold Chmielewski, prof. UJK

Uniwersytet Jana Kochanowskiego w Kielcach

Filia w Piotrkowie Trybunalskim

wchmielewski@op.pl 